\title{
High alkaline phosphatase activity in phosphate replete waters: The case of two macrotidal estuaries
}

\author{
Claire Labry, ${ }^{* 1}$ Daniel Delmas, ${ }^{1}$ Agnes Youenou, ${ }^{1}$ Julien Quere, ${ }^{1}$ Aude Leynaert, ${ }^{2}$ \\ Stephane Fraisse, ${ }^{3}$ Mélanie Raimonet, ${ }^{2}$ Olivier Ragueneau ${ }^{2}$ \\ ${ }^{1}$ Ifremer Dyneco/Pelagos, Plouzané, France \\ ${ }^{2}$ Laboratoire des Sciences de l’Environnement Marin, Institut Universitaire Européen de la Mer, UMR 6539, Plouzané, France \\ ${ }^{3}$ Universite de Rennes 1, UMR CNRS 6553 ECOBIO, Campus de Beaulieu, Rennes cedex, France
}

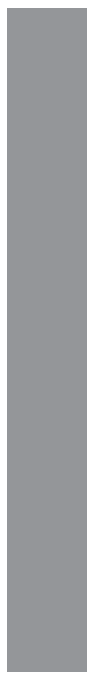

\begin{abstract}
The occurrence of alkaline phosphatase activity (APA) that hydrolyses organic phosphorus into phosphate $\left(\mathrm{PO}_{4}\right)$ is commonly related to $\mathrm{PO}_{4}$ deficiency of oceanic, coastal and fresh waters. APA is almost never investigated in $\mathrm{PO}_{4}$-rich estuaries, since very low activities are expected to occur. As a consequence, microbial mineralization of organic phosphorus into $\mathrm{PO}_{4}$ has often been ignored in estuaries. In this study, we examined the importance of potential APA and the associated microbial dynamics in two estuaries, the Aulne and the Elorn (Northwestern France), presenting two different levels of $\mathrm{PO}_{4}$ concentrations. Unexpected high potential APA was observed in both estuaries. Values ranged from 50 to $506 \mathrm{nmol} \mathrm{L}^{-1} \mathrm{~h}^{-1}$, which range is usually found in very phosphorus-limited environments. High potential APA values were observed in the oligohaline zone (salinity 5-15) in spring and summer, corresponding to a $\mathrm{PO}_{4}$ peak and a maximum bacterial production of particle-attached bacteria. In all cases, high potential APA was associated with high suspended particulate matter and total particulate phosphorus. The low contribution of the $0.2-1 \mu \mathrm{m}$ fraction to total APA, the strong correlation between particulate APA and bacterial biomass, and the close relationship between the production of particle-attached bacteria and APA, suggested that high potential APA is mainly due to particle-attached bacteria. These results suggest that the microbial mineralization of organic phosphorus may contribute to an estuarine $\mathrm{PO}_{4}$ production in spring and summer besides physicochemical processes.
\end{abstract}

\section{Introduction}

The ability of aquatic micro-organisms to acquire phosphorus (P) from organic phosphorus compounds, requires the action of alkaline phosphatases (AP), that hydrolyze phosphate monoesters into orthophosphate $\left(\mathrm{PO}_{4}\right)$ and organic matter. Alkaline Phosphatase Activity (APA) has been detected both in phytoplankton and bacterioplankton (Chrost and Overbeck 1987; Martinez and Azam 1993) even though studies relating to the occurrence of APA have mainly focused on phytoplankton (Perry 1976; Gage and Gorham 1985; Dyhrman 2005). APA occurs in aquatic environments as ectoenzymes and extracellular enzymes. Ectoenzymes are enzymes secreted by micro-organisms, which cross the cytoplasmic membrane but remain associated with its producer and hydrolyze substrates outside the cell (Chrost 1990). Extracellular enzymes are released into the surrounding environment. Alkaline phosphatases, as most of the ectoenzymes synthesized by aquatic micro-organisms, are mainly inducible catabolic enzymes. The

*Correspondence: clabry@ifremer.fr induction or repression of their synthesis is regulated by substrates or end-products availability or depletion (Chrost 1990).

The occurrence of APA has been commonly related to $\mathrm{PO}_{4}$ deficiency in marine waters (Li et al. 1998; Nausch 1998) and fresh waters (Berman 1970; Rose and Axler 1998). This APA sensitivity to $\mathrm{PO}_{4}$ has led many authors to use it as an indicator of phytoplankton P limitation. In aquatic environments supporting seasonal P limitation of micro-organism growth, AP synthesis was found to be induced when external $\mathrm{PO}_{4}$ concentrations fell below $0.05-0.1 \mu \mathrm{mol} \mathrm{L}^{-1}$ (Siuda and Chrost 1987; Nausch 1998). In these P-limited environments where free bacteria dominate the bacterial community, this threshold for the induction/repression of AP synthesis was found to be relevant for both phytoplankton and free bacteria (Labry et al. 2005). In systems where $\mathrm{PO}_{4}$ concentrations are above this threshold throughout the year, studies on APA are scarce since substantial APA is unlikely to occur. This is the case for numerous estuaries whose $\mathrm{PO}_{4}$ concentrations are usually above $0.3 \mu \mathrm{mol} \mathrm{L}^{-1}$ (Prastka et al. 1998; Cai and Guo 2009). As a consequence, APA is almost never investigated in $\mathrm{PO}_{4}$-rich estuaries. Nevertheless, estuarine studies with a few 
measurements of APA have reported high velocities, although the authors did not point out these paradoxical findings regarding the $\mathrm{PO}_{4}$ concentrations (Hernández et al. 2000, Karrasch et al. 2003). This high APA, if confirmed, could affect $P$ dynamics in estuaries by providing an additional source of $\mathrm{PO}_{4}$ from the mineralization of organic $\mathrm{P}$. The $\mathrm{PO}_{4}$ produced could be then exported to the coastal sea.

In contrast, investigations on factors affecting $\mathrm{P}$ dynamics in estuaries have mainly focused on the geochemical aspect, concentrating on physicochemical processes to explain the partitioning between the different species of $\mathrm{P}$ (Froelich 1988; Prastka et al. 1998). These processes, which actually contribute to $\mathrm{P}$ dynamics, are adsorption/desorption of $\mathrm{PO}_{4}$ from particulate inorganic phosphorus (Conley et al. 1995; Deborde et al. 2007), release of $\mathrm{PO}_{4}$ from the reduction of metal oxyhydroxide (Fang 2000; Van der Zee et al. 2007; Lin et al. 2012), and diffusive $\mathrm{PO}_{4}$ fluxes from sediments (Andrieux-Loyer et al. 2008). The microbial mineralization of organic phosphorus into $\mathrm{PO}_{4}$ has been given little attention.

However, it is well known that bacterial production is particularly high in estuaries, with the highest values usually found in the maximum turbidity zone (Rochelle-Newall et al. 2004; Servais and Garnier 2006). This high carbon production is supplied by the biodegradability of organic carbon, particulate organic carbon being the main source (Garnier et al. 2008). Mineralization in the maximum turbidity zone is favored in macrotidal estuaries by tidal effect on the longer residence times of both water and suspended matter (Etcheber et al. 2007). In addition, particle-attached bacteria are the major contributors to this high bacterial production (Crump and Baross 1996; Ploug et al. 2002). Thus, the importance of bacterial activity on the carbon cycle is clearly recognized in estuaries but has been completely underestimated in studies regarding the P cycle. Furthermore, APA typically interacts with the carbon cycle since the hydrolysis of organic P compounds liberates organic carbon moiety which may supply bacterial carbon demand (Chrost 1991; Hoppe and Ullrich 1999). Indeed, for bacteria, the mechanisms of APA regulation appear more complex than those for phytoplankton. The release of organic carbon moiety implies that carbon depletion or availability could also affect the induction or repression of phosphatase synthesis (Hoppe and Ullrich 1999; Hoppe 2003; Steenbergh et al. 2011). Therefore, the enzymatic $\mathrm{PO}_{4}$ regeneration obviously impacts on the regeneration of organic carbon.

In marine and lake aggregates, it is well established that specific enzymatic activities of particle-attached bacteria are higher than activities of free surrounding bacteria (Karner and Herndl 1992; Grossart and Simon 1998). In addition, only a little part of the hydrolysates produced by this intense hydrolytic enzyme activity would be taken up by particleattached bacteria (Smith et al. 1992), which would conduct to an enrichment of the surrounding waters in hydrolysates.
Macrotidal estuaries are the sites of particle accumulation and high APA has been reported earlier in zones of high particle concentrations such as marine aggregates (Smith et al. 1992; Zoppini et al. 2005) or benthic nepheloid layers of aquatic environment (Kim et al. 2007). Consequently, we suspect that APA of particle-attached bacteria could contribute to the $\mathrm{PO}_{4}$ regeneration in macrotidal estuaries, especially in the maximum turbidity zone.

The aim of this study is to test the potential importance of the microbial mineralization of organic $\mathrm{P}$ into $\mathrm{PO}_{4}$ in macrotidal estuaries. As APA is usually controlled by $\mathrm{PO}_{4}$ concentrations, we investigated two macrotidal estuaries presenting two different levels of $\mathrm{PO}_{4}$ concentrations, the Aulne and Elorn estuaries in North-western France. In addition, the Aulne and Elorn estuaries display two different types of morphology and hydrodynamics, which impact on the residence time of waters and particles, and, as a consequence, on microbial dynamics. The Aulne and Elorn estuarine waters were sampled at a seasonal scale for phosphorus speciation and microbial dynamics by determining total and size-fractionated potential APA, bacterial biomass and production, $\mathrm{PO}_{4}$ uptake rates, Chlorophyll a $(\mathrm{Chl} a)$ and pheopigment concentrations. APA was determined at saturating concentration of substrate. The maximum reaction velocity $\left(V_{\mathrm{m}}\right)$ obtained, called hereafter "potential APA," represents the enzymatic potentialities developed by microorganisms (e.g., cell enzymatic equipment). Contrary to APA measurement at trace concentration of substrate, potential APA measurement allows the comparison between stations, seasons, and with other surveys. This study is the first to emphasize the high levels of potential APA in $\mathrm{PO}_{4}$-rich macrotidal estuaries, in contrast to the well-documented inverse relationship between APA and $\mathrm{PO}_{4}$ availability in aquatic environments. It brings new insights into processes governing $\mathrm{P}$ dynamics in estuaries, mineralization of particulate organic phosphorus via the AP synthesis contributing to the estuarine production of $\mathrm{PO}_{4}$.

\section{Materials and methods}

\section{Study area}

The Aulne and Elorn estuaries are two temperate macrotidal (semi-diurnal tide) estuaries supplying up to $85 \%$ of fresh water inputs to the semi-enclosed Bay of Brest, in Northwestern France (Fig. 1). The linear morphology of the Elorn estuary, more directly exposed to oceanic hydrodynamic influences, is favorable to a shorter residence time of water and particles than the meandering Aulne estuary (Raimonet et al. 2013). With a drainage basin of approximately $1806 \mathrm{~km}^{2}$, the Aulne estuary supplies most of the fresh waters to the Bay of Brest (60-80\%). The surface area of the Elorn river basin is $353 \mathrm{~km}^{2}$ only. The catchment areas of the Aulne and Elorn rivers are both characterized by intense agricultural activities. Urbanization is greater in the Elorn 


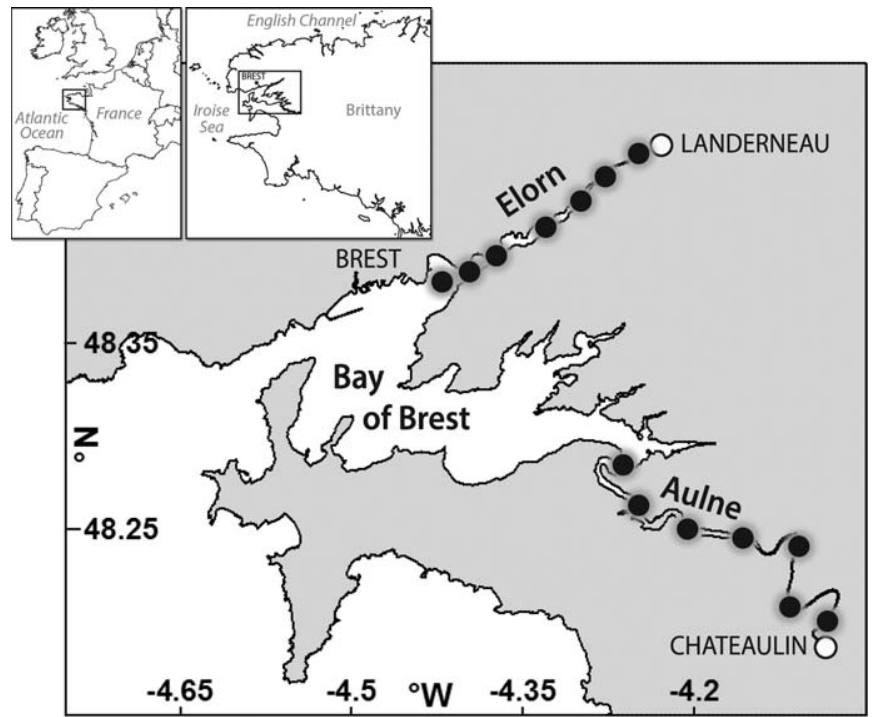

Fig. 1. Location of the Aulne and Elorn estuaries supplying the semienclosed Bay of Brest, in North-western France. Dark points are indicative of the sampling positions. Locations varied from one season to another depending on river flow and tide.

catchment area and a water-treatment plant is established in Landerneau (Fig. 1).

\section{Sampling strategy}

Sampling was carried out on two consecutive days in Winter (9-10 February), Spring (18-19 May), Summer (30 June-01 July) and Autumn (12-16 November) 2009. Tidal coefficients were 101, 41, 53, and 73, respectively. Surface seawater samples were collected along a salinity gradient, from the Elorn river (first day) or the Aulne river (second day) to the Bay of Brest. All stations were affected by tides and sampling was performed from mid-tide to high tide, beginning by the upstream limit of saline intrusion (at 0 salinity) then approximately every 5 salinity interval up to a salinity of 30-32. For each salinity gradient, 7 surface seawater samples were collected $(\sim 50 \mathrm{~cm}$ depth). The sampling locations illustrated in Fig. 1 are indicative since the spatial distribution of salinity ranging from 0 to 30-32 throughout the Aulne or the Elorn estuary depends on river discharges and tides. Water depths varied from $3 \mathrm{~m}$ at the upstream limit of saline intrusion to $15 \mathrm{~m}$ at salinity 30-32. Water samples were collected using a Niskin bottle, stored at in situ temperature for less than $2-3 \mathrm{~h}$ before sample treatment. Filtrations for speciation of dissolved (filtrates) and particulate (filters) phosphorus, for Chl $a$ and suspended particulate matter (SPM) were carried out. Additionally, total and sizefractionated potential APA, bacterial biomass, and production were measured. Phosphate uptake rates were measured in May and July and bacterial production was sizefractionated in July and November.
Measurements of SPM, Chl $\boldsymbol{a}$ and bacterial abundance

SPM concentrations were obtained by the filtration of seawater on preweighed $47 \mathrm{~mm}$ glass fiber filters (Whatman ${ }^{\circledR}$ $\mathrm{GF} / \mathrm{F})$. The filters were rinsed with Milli-Q water to remove sea salts. Filter samples were weighed after drying for $3 \mathrm{~h}$ at $50^{\circ} \mathrm{C}$. Total Chl $a$ and pheopigments (Pheo) were determined in particulate organic matter collected on $25 \mathrm{~mm}$ Whatman ${ }^{\circledR}$ $\mathrm{GF} / \mathrm{F}$ filters. The filters were frozen $\left(-20^{\circ} \mathrm{C}\right)$ and analyzed later by acidification fluorometric procedure in 90\% acetone extracts (Holm-Hansen et al. 1965). Samples for total bacterial abundance were preserved with borate buffered formalin ( $2 \%$ final concentration). Total bacteria were determined by treating samples with $5 \mathrm{mmol} \mathrm{\textrm {L } ^ { - 1 }}$ final concentration of pyrophosphate, as a sequestering/deflocculating agent, for 30 min and then sonicated for $40 \mathrm{~s}$ at $100 \mathrm{~W}$ to disperse the bacteria fixed to estuarine particles (Velji and Albright 1986). Then bacteria were enumerated after staining with 4',6-diamidino-2-phenylindole (DAPI, Porter and Feig 1980).

Measurements of dissolved and particulate phosphorus

Phosphorus species, which were analyzed in the present study, include dissolved inorganic and organic phosphorus (DIP, DOP) and Total Particulate Phosphorus (TPP). Since all methods consist in converting forms of combined $\mathrm{P}$ into $\mathrm{PO}_{4}$, the subsequent quantification of $\mathrm{PO}_{4}$ was achieved by the phosphomolybdate-blue colorimetric reaction (Murphy and Riley 1962) using segmented flow analysis (Aminot et al. 2009).

Samples for the determination of DIP and DOP were very carefully filtered on precombusted $\left(12 \mathrm{~h}\right.$ at $\left.480^{\circ} \mathrm{C}\right) 25 \mathrm{~mm}$ Whatman $^{\circledR} \mathrm{GF} / \mathrm{F}$ with a syringe filtration system. Filtrates were deep frozen $\left(-20^{\circ} \mathrm{C}\right)$. Samples for TPP were filtered on precombusted $25 \mathrm{~mm}$ Whatman ${ }^{\circledR} \mathrm{GF} / \mathrm{F}$ filters and filters were deep frozen.

DOP was measured by a segmented flow automated method with on-line photo-oxidation according to Aminot and Kérouel (2001). Concentrations of total dissolved phosphorus and DIP were measured in parallel from the same sample, using two independent manifolds. The measurement of total dissolved phosphorus comprised UV-peroxide oxidation and colorimetric $\mathrm{PO}_{4}$ determination. Dissolved organic phosphorus concentration was obtained by subtracting DIP, measured simultaneously in a parallel channel. In this method, polyphosphates do not interfere in the DOP determination.

TPP was determined as precisely described in Labry et al. (2013), the original method being that of Solórzano and Sharp (1980). Filters placed in a borosilicate vial were dried with $2 \mathrm{~mL}$ of $0.017 \mathrm{~mol} \mathrm{~L}^{-1} \mathrm{MgSO}_{4}$ in a $95^{\circ} \mathrm{C}$ oven for $3 \mathrm{~h}$, then ashed at $480^{\circ} \mathrm{C}$ for $2 \mathrm{~h}$. After cooling, they were acidhydrolyzed in $5 \mathrm{~mL}$ of $0.2 \mathrm{~mol} \mathrm{~L}{ }^{-1} \mathrm{HCl}$ in an $80^{\circ} \mathrm{C}$ oven for $30 \mathrm{~min}$. Unlike the evaporation step, the baking and hydrolysis steps were done with tightly fitted lids. $10 \mathrm{~mL}$ of Milli-Q deionized water was added and the vials were 
centrifuged at $3000 \mathrm{rpm}$ for $5 \mathrm{~min}$ before $\mathrm{PO}_{4}$ measurement on supernatants.

\section{Potential alkaline phosphatase activity}

Two main strategies are commonly used to investigate microbial enzymatic activities and particularly phosphatases (Chrost 1990; Hoppe 2003). A first strategy consists in focusing on the enzyme biochemistry, so that enzymes (intracellular and/or ectoenzymes) may be extracted and incubated under more or less standardized conditions (defined by composition, concentration, and $\mathrm{pH}$ of a buffer solution; fixed temperature ...). A second strategy focuses on the microbial enzymatic response to actual environmental conditions, so that the incubation conditions are kept as closed as possible to the in situ natural conditions, besides substrate addition. In a lot of marine studies, the protocols used vary between these two strategies (buffer and $\mathrm{pH}$ control, temperature, substrate concentrations, ...), which impact on meaningful comparisons between studies.

The aim of our approach was to measure ectoenzymatic $(0.2-1 \mu \mathrm{m}$ and $>1 \mu \mathrm{m})$ and extracellular $(<0.2 \mu \mathrm{m})$ activities in $\mathrm{pH}$, temperature, and chemical conditions which were the closest possible to those prevailing in situ. We conducted incubations with minimal disturbance (prefiltration and substrate addition only). The fluorometric method with methylumbelliferyl phosphate (MUF-P) as substrate (Hoppe, 1983; Ammerman 1993) was used on unfiltered (total APA) and two prefiltered seawater samples $(<0.2 \mu \mathrm{m}$ APA and $<1 \mu \mathrm{m}$ APA). Low volumes $(<30 \mathrm{~mL})$ were filtered through a $47 \mathrm{~mm}$ polycarbonate membrane $(0.2 \mu \mathrm{m}$ or $1 \mu \mathrm{m})$ using a low suction $<50 \mathrm{~mm} \mathrm{Hg}$ to avoid filter clogging and reduce cell stress. A saturating concentration of MUF-P $\left(128 \mu \mathrm{mol} \mathrm{L}^{-1}\right)$ was used so that the whole results of APA presented in the present paper are indicative of potential APA $\left(V_{\mathrm{m}}\right)$. Twomilliliter of duplicate samples and 4\% formalin-killed controls were incubated with $50 \mu \mathrm{L}$ of substrate solution for 5-6 h. Incubations were conducted in the dark at in situ temperature and $\mathrm{pH}$. The hydrolysis reaction was stopped by the addition of $4 \%$ final concentration of formalin, and both samples and controls were deep frozen. Fluorescence, produced by the methylumbelliferon (MUF) released, was measured by flow injection analysis (Delmas et al. 1994) coupled with a fluorescence spectrometer (Kontron SFM 25, excitation at $364 \mathrm{~nm}$ and emission at $460 \mathrm{~nm}$ ). The MUF fluorescence yield varies with $\mathrm{pH}$ below 10 and mainly in the range 7-9 (Hoppe 1983; Chrost and Krambeck 1986). In estuaries, such as Aulne and Elorn, $\mathrm{pH}$ varies along the salinity gradient between 7.0 (river freshwater) and 8.2 downstream (Y. Bozec pers. comm.). Thus, whatever the $\mathrm{pH}$ of incubation, the final measurement of the MUF fluorescence should be made at constant and optimum $\mathrm{pH}>10$ for quantitative fluorescence measurement. A buffered solution of borate (0.1 mol L $\left.^{-1}, \mathrm{pH} 10.5\right)$ was used as the carrier fluid, providing maximum MUF fluorescence. The system was previously calibrated with MUF solutions $\left(2 \mathrm{nmol} \mathrm{L} \mathrm{L}^{-1}-2 \mu \mathrm{mol} \mathrm{L} \mathrm{L}^{-1}\right)$. The $>1 \mu \mathrm{m}$ APA was calculated as the difference between total APA and $<1 \mu \mathrm{m} \mathrm{APA}$, and the $0.2-1 \mu \mathrm{m}$ APA as the difference between $<1 \mu \mathrm{m}$ APA and $<0.2 \mu \mathrm{m}$ APA. The $1 \mu \mathrm{m}$ filtration threshold was chosen to ensure that the $0.2-1 \mu \mathrm{m}$ fraction contained free bacteria only since estuarine picoplankton would not have passed through $1 \mu \mathrm{m}$ filters.

\section{Bacterial production}

Bacterial production was estimated by the ${ }^{3} \mathrm{H}$-methyl-thymidine (TdR) incorporation method (Fuhrman and Azam 1982). Triplicate samples (5 mL) and TCA-killed controls (5\% final concentration) were incubated with $40 \mathrm{nmol} \mathrm{L}^{-1}$ final concentration of TdR (50 $\mathrm{Ci} \mathrm{mmol}{ }^{-1}$ ) at in situ temperature for $30 \mathrm{~min}$ to $1 \mathrm{~h}$. The rate of TdR incorporation into DNA was converted into cell production, using $2.18 \times 10^{18}$ cells produced per mole of thymidine incorporated (Fuhrman and Azam 1982). Then, bacterial carbon production was estimated assuming a cell content of $20 \mathrm{fg}$ C. In summer, additional prefiltration onto $3 \mu \mathrm{m}$ was carried out to estimate the production of free $(<3 \mu \mathrm{m})$ and particle-attached $(>3 \mu \mathrm{m})$ bacteria. The production of particle-attached bacteria was calculated by subtracting $<3 \mu \mathrm{m}$ production from the total production. By choosing $3 \mu \mathrm{m}$ as the threshold of filtration, the $>3 \mu \mathrm{m}$ fraction should contain particle-attached bacteria only. Contributions of particle-attached bacteria to total bacterial production were interpreted as minimum contributions.

\section{Phosphate uptake rate}

Rates of $\mathrm{PO}_{4}$ uptake $\left(V_{\mathrm{p}}\right)$ were measured using the ${ }^{33} \mathrm{PO}_{4}$ incorporation technique in May and July. $180 \mathrm{~mL}$ of each estuarine water were distributed into polycarbonate flasks, and incubations started with the addition of carrier-free $50 \mu \mathrm{Ci}{ }^{33} \mathrm{PO}_{4}^{3-}$ (1.85 MBq). 4\% formalin-killed controls were prepared to subtract background and abiotic adsorption. Incubations were performed under $130 \mu \mathrm{mol}$ photons $\mathrm{m}^{-2} \mathrm{~s}^{-1}$ at in situ temperature, and ended after $5 \mathrm{~h}$ by the addition of $4 \%$ formaldehyde. Duplicate samples and controls $(9 \mathrm{~mL})$ were immediately filtered on $0.22 \mu \mathrm{m}$ Millipore filters. The filters were rinsed twice with $5 \mathrm{~mL}$ of $0.2 \mu \mathrm{m}$ filtered seawater of corresponding salinity and stored with $4 \mathrm{~mL}$ of scintillation cocktail until they were counted with a liquid scintillation counter.

\section{Results}

\section{Hydrology and plankton dynamics}

Water temperature and climatology were typical of each season for waters in a temperate climate (Table 1). Precipitations were higher throughout winter than in spring and summer, resulting in higher river discharges (Table 1). After summer months of low water, river discharges had just begun to increase, ten days before the sampling date in autumn. The two estuaries were obviously submitted to the same hydroclimatic forcing. However, in agreement with 
Table 1. Range of temperature (T), River discharges, SPM, Chlorophyll $a(\mathrm{Chl} a)$, contribution of pheopigments (Pheo) to total pigments (Chl $a$ and Pheo), bacterial biomass (Bact), and production (BP) in the salinity gradient of the Aulne and Elorn estuaries in February, May, July, and November 2009. The range of river discharges 15 days before the sampling date are indicated

\begin{tabular}{|c|c|c|c|c|c|c|c|}
\hline February & $8.0-8.6$ & $15-44$ & $42-235$ & - & - & $0.6-4.7$ & $14-62$ \\
\hline May & $12.0-13.8$ & $4-6$ & $26-49$ & $1.8-16.0$ & $36-54$ & $1.4-3.0$ & $64-234$ \\
\hline July & $17.9-21.4$ & $2-3$ & $8-49$ & $5.3-20.4$ & $10-32$ & $2.2-3.7$ & $80-320$ \\
\hline \multicolumn{8}{|l|}{ Aulne } \\
\hline February & $7.2-7.8$ & 116-299 & $3-188$ & - & - & $0.4-10.7$ & $7-30$ \\
\hline May & $14.5-15.3$ & $12-17$ & $10-34$ & $1.0-13.2$ & $14-46$ & $0.6-4.5$ & $18-225$ \\
\hline July & $20.6-23.9$ & $4-9$ & $28-86$ & $3.5-33.7$ & $23-46$ & $0.8-7.8$ & $52-343$ \\
\hline November & $11.2-12.7$ & $4-50$ & $7-53$ & $0.3-1.0$ & $34-79$ & $0.8-4.4$ & 24-188 \\
\hline
\end{tabular}

their drainage basin area, the Aulne river discharges were 111 times higher than those of the Elorn throughout the year 2009. The high winter river discharges resulted in a high supply of particles, SPM reaching 188 and $235 \mathrm{mg} \mathrm{L}^{-1}$ in the Aulne and Elorn rivers, respectively (Table 1, Fig. 2a,b). These are the maximum concentrations observed throughout the survey. During high winter flows, SPM decreased rapidly in the low-salinity area $(0-5$, Fig. $2 a, b)$, whereas, during the low water period (May, July), high SPM levels were observed in the oligohaline area (salinity 5-15, Fig. 2c,d). In autumn, while river discharges had just begun to increase, the SPM evolution pattern was similar to that observed in winter for the Aulne estuary, i.e., a sharp decrease upstream of the salinity gradient, whereas high SPM remained in the oligohaline area in the Elorn estuary (Fig. 2a,b).

High Chl a concentrations were observed in spring and summer with the maximum values often associated with the maximum SPM (Fig. 2g,h). In autumn, Chl $a$ concentrations were low (Table 1, Fig. 2e,f). Pheopigments contributed significantly to total pigments (Chl $a$ and Pheo) in spring and summer, peaking in autumn (Table 1). This indicated the presence of senescent phytoplankton cells. In contrast, Pheo contribution was exceptionally low in July throughout the salinity gradient of the Elorn estuary, suggesting the presence of "fresh, non degraded" phytoplankton cells. Unlike Chl $a$ concentrations, the range of bacterial abundance in the salinity gradient remained almost unchanged from February to November (Table 1). In contrast, bacterial production displayed a sharp increase from winter to summer and a decline in autumn. Bacterial abundance and production followed the evolution of SPM and TPP in the salinity gradient with the highest levels observed where SPM and TPP were the highest (upstream of the estuaries in winter, and, in the oligohaline zone in spring and summer, not figured). The summer pattern in the Elorn estuary was an exception since the maximum levels in bacterial production were found in the downstream estuarine part (salinity 15-25).

\section{Variations in P concentrations along the Aulne and Elorn estuaries}

Phosphate concentrations in the Elorn river were always higher (2.5-14 times) than in the Aulne river (Fig. 3a-d). As a consequence, in the low salinity part of the estuaries, $\mathrm{PO}_{4}$ was also always higher (1.5-5 times) in the Elorn than in the Aulne estuary. In the downstream part of the estuaries, $\mathrm{PO}_{4}$ concentrations tended to be similar as a result of the mixing of both estuarine waters in the Bay of Brest. Throughout the survey, $\mathrm{PO}_{4}$ concentrations were always higher than 0.16 and $0.48 \mu \mathrm{M}$, in the Aulne and Elorn estuaries, respectively. The behavior of $\mathrm{PO}_{4}$ in the salinity gradient displayed two typical seasonal patterns. In winter and autumn, $\mathrm{PO}_{4}$ concentrations showed a rather conservative behavior with salinity in the Elorn estuary, and a gradual increase in the salinity gradient in the Aulne estuary (Fig. 3a,b). In contrast, in spring and summer, $\mathrm{PO}_{4}$ concentrations of both estuaries showed a rise with increasing salinity up to 5 or 10 , then fell after salinity $>10$ (Fig. 3c,d). In summer, $\mathrm{PO}_{4}$ even reached a concentration 5 times higher at salinity 10 than in the Aulne river waters (Fig. 3d). There was clearly an estuarine production of $\mathrm{PO}_{4}$ in spring and summer in comparison to river waters. By way of contrast, DOP concentrations remained relatively constant in the salinity gradient at each season, for both estuaries, and always markedly lower than $\mathrm{PO}_{4}$ concentrations (Fig. 3a-d).

As previously described for SPM, the maximum values of TPP were found in winter in riverine waters and the upstream part of the estuaries (Fig. 3e-h). The variations in TPP concentrations with salinity showed a sharp decrease between riverine waters and the upstream part of the estuaries (salinity 5) in winter and autumn, followed by a gradual fall-off (Fig. 3e,f). Similarly to $\mathrm{PO}_{4}$ behavior, a maximum of 


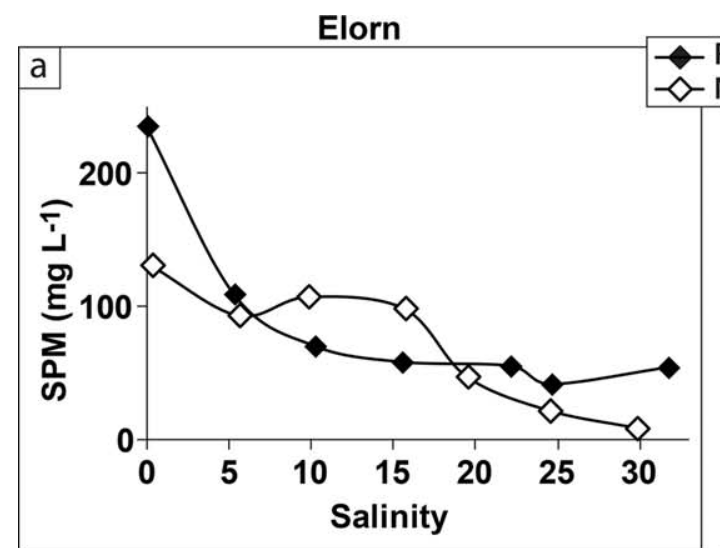

Aulne

Feb.
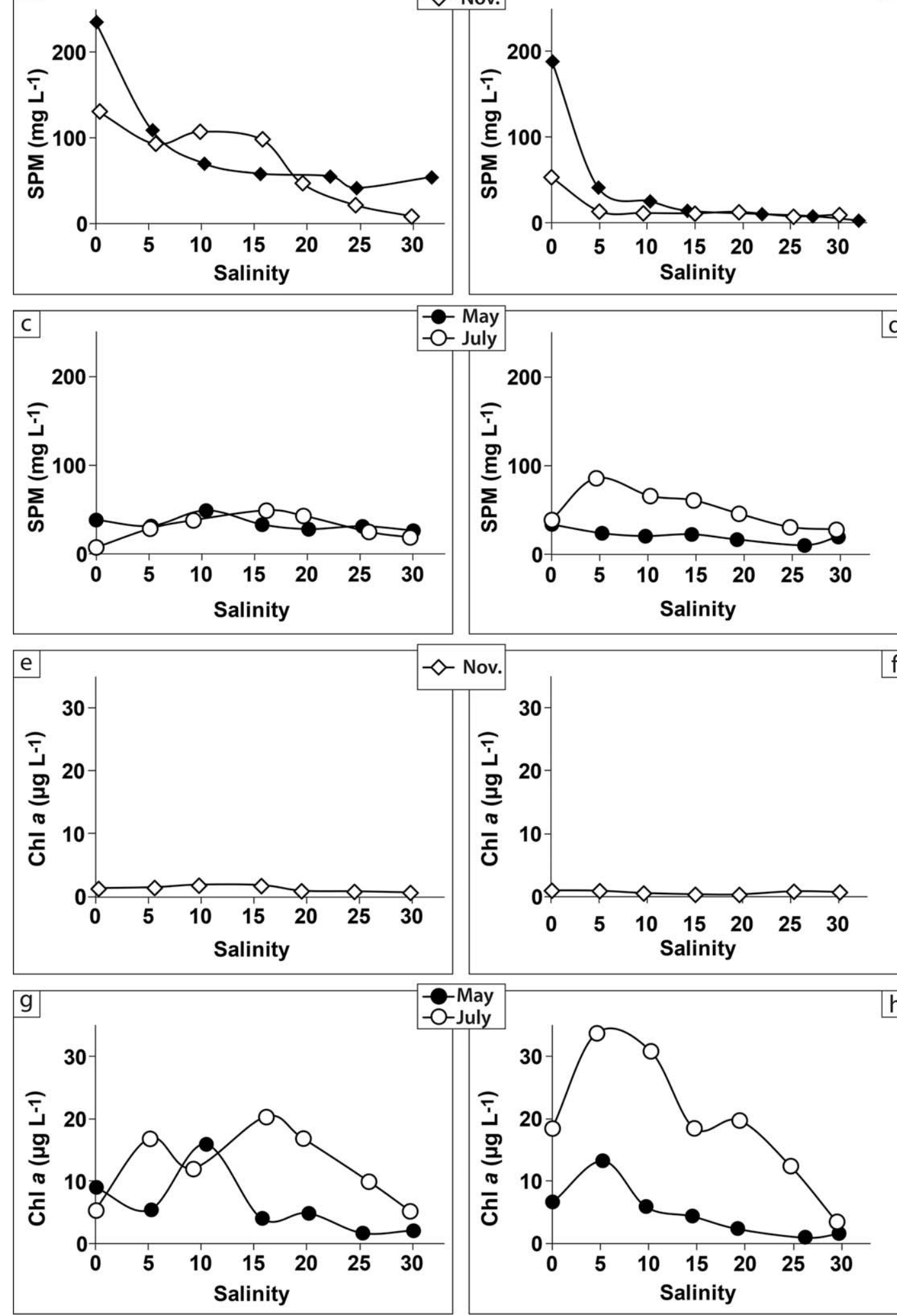

May

July

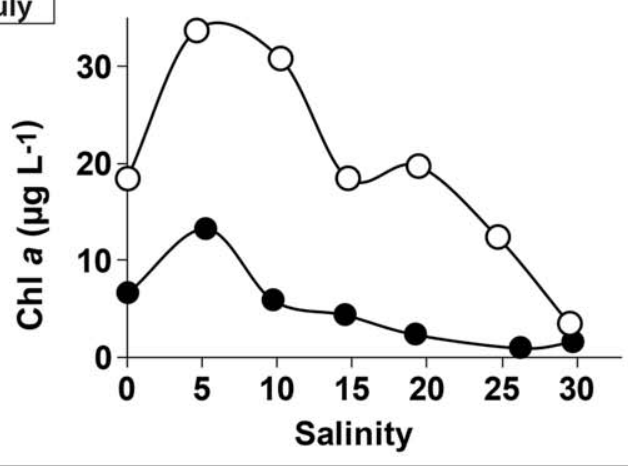

Fig. 2. Concentration of suspended particulate matter (SPM; $\mathrm{a}, \mathrm{b}, \mathrm{c}, \mathrm{d}$ ) and Chlorophyll $a$ (Chl $a$; e, $\mathrm{f}, \mathrm{g}, \mathrm{h}$ ) in the salinity gradient of the Elorn (left) and Aulne (right) estuaries in February, May, July and November 2009. 

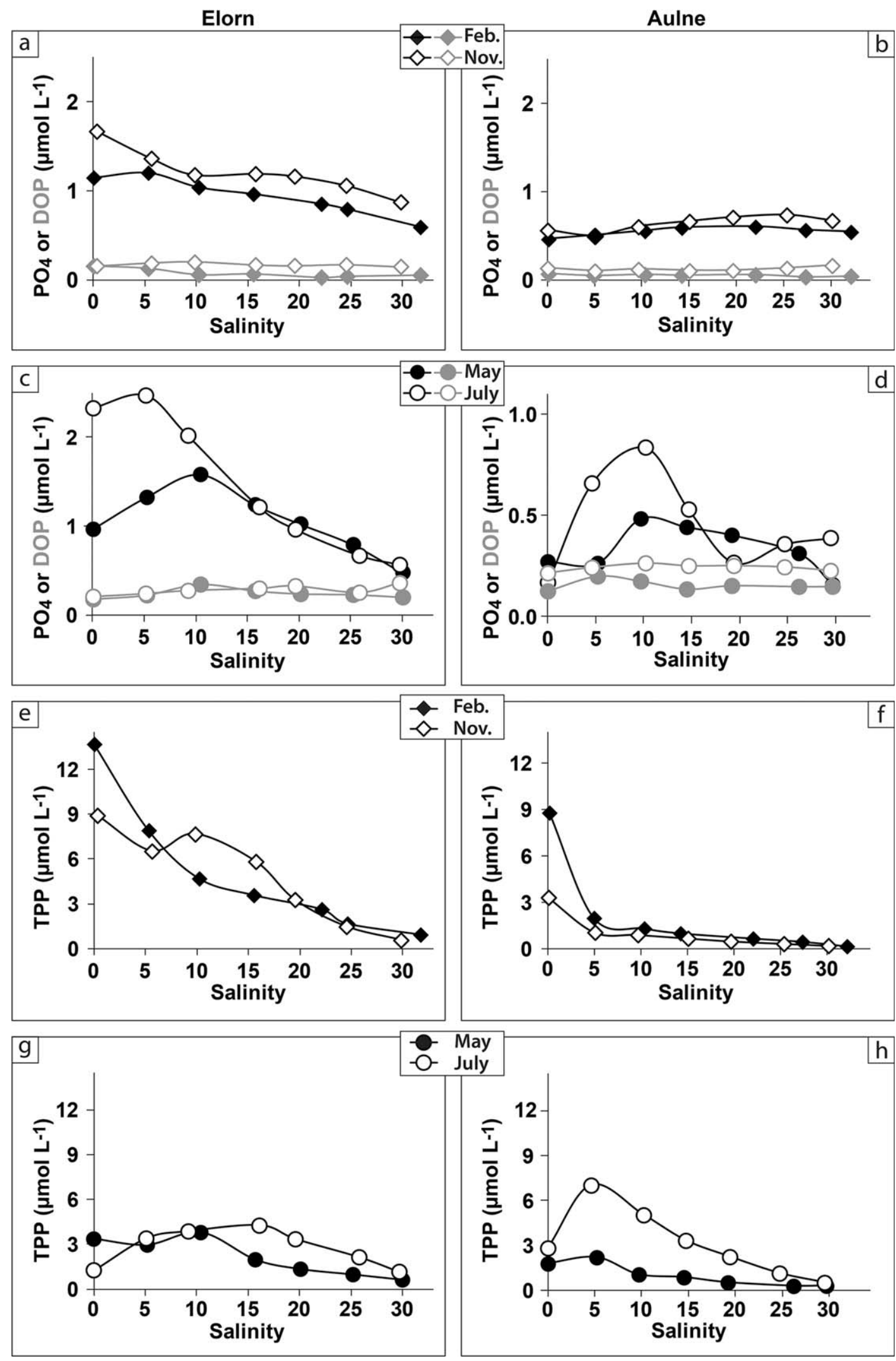

Fig. 3. Concentration of phosphate $\left(\mathrm{PO}_{4} ; \mathrm{a}, \mathrm{b}, \mathrm{c}\right.$, d; dark dots), dissolved organic phosphorus (DOP; $a, b, c$, d, grey dots) and total particulate phosphorus (TPP; e, f, g, h) in the salinity gradient of the Elorn (left) and Aulne (right) estuaries in February, May, July and November 2009. 

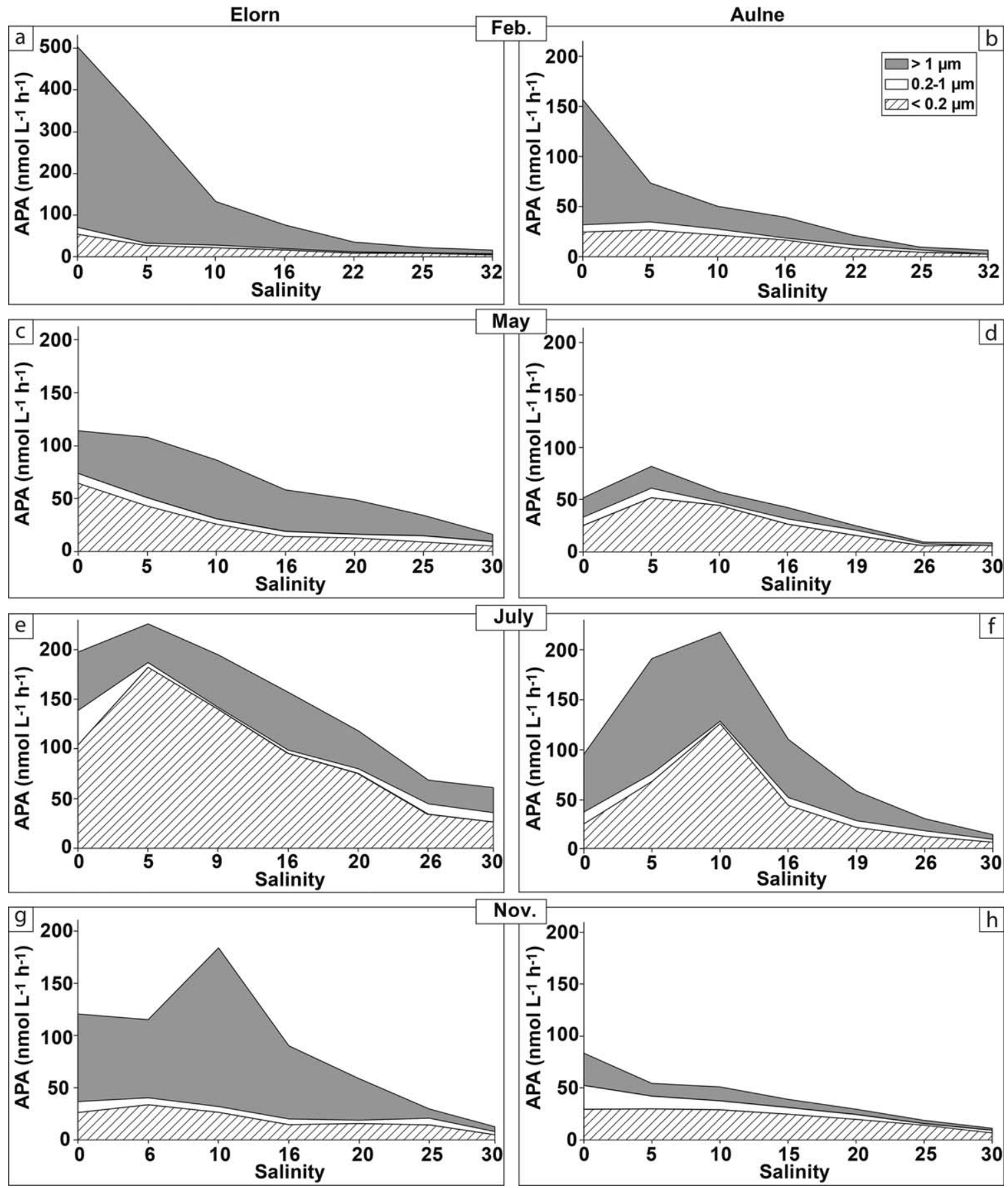

Fig. 4. Size-fractionated potential APA in the salinity gradient of the Elorn (left) and Aulne (right) estuaries in February (a, b), May (c, d), July (e, f) and November $(g, h) 2009$.

TPP was observed in the oligohaline area (5-15) in spring and summer (Fig. 3g,h).

\section{Variations in potential APA}

Against all expectations, potential APA from the Aulne and Elorn estuaries exhibited very high values (Fig. 4). Total

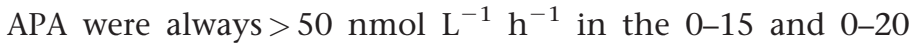

salinity range of the Aulne and Elorn estuary, respectively.

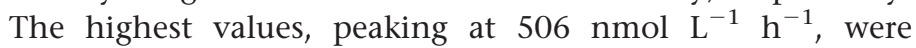
found, in winter, in riverine waters and the upstream part of the estuaries, and, in summer, between salinity 5 and 15 (APA > $150 \mathrm{nmol} \mathrm{L}{ }^{-1} \mathrm{~h}^{-1}$ ). Total APA were similarly high in the Elorn and the Aulne estuary. The evolution of total APA in the salinity gradient closely followed that of SPM and 
TPP. A sharp decrease was observed in the low-salinity area (0-5) in winter (Fig. 4a,b) whereas a maximum occurred in the oligohaline zone (5-15) in spring and summer (Fig. $4 \mathrm{c}-\mathrm{f})$. In autumn, maximum APA remained in the oligohaline zone in the Elorn estuary where TPP and SPM were still high (Fig. 4g). In contrast, the APA pattern was already similar to the winter situation in the Aulne estuary (Fig. 4h).

To a better understanding of the origin of potential APA, size-fractionation was carried out. The $0.2-1 \mu \mathrm{m}$ size fraction was the lowest contributor to total APA throughout the survey for both estuaries, mean contribution to total APA ranging from $5 \%$ to $18 \%$ (Table 2, Fig. 4). The $>1 \mu \mathrm{m}$ fraction dominated total APA in the Elorn estuary, except in July, when its contribution was only half that of the dissolved fraction (Table 2, Fig. 4e). In the Aulne estuary, the $>1 \mu \mathrm{m}$ fraction was the major contributor in winter and summer and the dissolved fraction dominated in spring and autumn (Table 2, Fig. 4). The dissolved fraction was always significant (mean $>38 \%$ ).

The dependence of potential APA on hydrochemical (temperature, $\mathrm{PO}_{4}, \mathrm{DOP}$, and TPP) and biological parameters was analyzed. Particulate and dissolved APA was not correlated with temperature (Tables 3 and 4). They were either positively correlated with $\mathrm{PO}_{4}$ (Table 3 ) or not correlated with $\mathrm{PO}_{4}$ (Table 4). However, no inverse hyperbolic relationship was observed between potential APA and $\mathrm{PO}_{4}$ in the present study, in contrast to the usual regulation scheme of APA. Particulate APA was not correlated with DOP, whereas dissolved APA was significantly correlated with DOP. The highest correlations were found with TPP, bacterial biomass, and SPM for both estuaries. Bacterial production correlated significantly with potential APA in the Aulne estuary (Table 4). In fact the highest APA observed in the Aulne estuary were found in summer when bacterial production was maximum (Fig. 4, Table 1). In summer, the evolution of APA along the

Table 2. Relative size contribution (mean \pm standard deviation, $n=7$ ) to total APA in the salinity gradient of the Aulne and Elorn estuaries in February, May, July and November 2009

\begin{tabular}{llcl}
\hline & \multicolumn{3}{c}{ Contribution to total APA (\%) } \\
\cline { 2 - 4 } & $<\mathbf{0 . 2 \mu \mathrm { m }}$ & $\mathbf{0 . 2}-\mathbf{1} \boldsymbol{\mu \mathrm { m }}$ & $>\mathbf{1} \boldsymbol{\mu m}$ \\
\hline Elorn & & \\
$\quad$ February & $23 \pm 12$ & $5 \pm 4$ & $71 \pm 15$ \\
May & $35 \pm 11$ & $11 \pm 7$ & $54 \pm 13$ \\
July & $60 \pm 13$ & $8 \pm 8$ & $31 \pm 8$ \\
November & $29 \pm 13$ & $10 \pm 8$ & $61 \pm 21$ \\
Aulne & & & \\
February & $38 \pm 11$ & $10 \pm 8$ & $51 \pm 16$ \\
May & $64 \pm 9$ & $12 \pm 10$ & $24 \pm 8$ \\
July & $43 \pm 10$ & $10 \pm 7$ & $47 \pm 12$ \\
November & $60 \pm 13$ & $18 \pm 6$ & $22 \pm 8$ \\
\hline
\end{tabular}

haline gradient closely followed that of bacterial production and $\mathrm{PO}_{4}$ (Fig. 5a), suggesting a close link between APA, its potential contributors (bacteria) and the estuarine production of $\mathrm{PO}_{4}$. In addition, the production of particle-attached bacteria ( $>3 \mu \mathrm{m}$ fraction) dominated total bacterial production in the oligohaline area (67-85\%, Fig. 5b). In autumn, the production of particle-attached bacteria contributed to $36-51 \%$ and $36-68 \%$ of the total bacterial production at the peak of the maximum APA in the Aulne and Elorn estuary, respectively. This contribution was weaker in July in the Elorn estuary (20-44\%). The link between potential APA and Chl $a$ was also investigated, even though winter values of Chl $a$ were missing. The highest relationships were observed between particulate APA and Chl $a$ in the Aulne estuary, and between the dissolved APA and Chl $a$ in the Elorn estuary (Tables 3 and 4).

To compare the potential production rate of $\mathrm{PO}_{4}$ via APA and the loss of $\mathrm{PO}_{4}$ by biological absorption, $\mathrm{PO}_{4}$ uptake rates (Vp) were measured in May and July (Fig. 6). For both estuaries, $\mathrm{PO}_{4}$ uptake rates increased from May $\left(<16 \mathrm{nM} \mathrm{L}^{-1}\right.$ $\mathrm{h}^{-1}$ ) to July (15-95 $\mathrm{nM} \mathrm{L}^{-1} \mathrm{~h}^{-1}$ ) and maximum uptake rates were generally observed at intermediate salinities (10-20). The gap between potential APA and $\mathrm{PO}_{4}$ uptake rates was maximum in the low salinity part of estuaries (salinity $<15$ ). In this oligohaline zone, potential APA was 6-29 times higher than the $\mathrm{PO}_{4}$ uptake rates, whereas potential APA was only 2-6 times higher in the downstream part of the estuaries.

\section{Discussion}

Several physicochemical processes are known to affect the partitioning between the different species of $\mathrm{P}$ in estuaries: adsorption/desorption of $\mathrm{PO}_{4}$ from particles, release of $\mathrm{PO}_{4}$ from the reduction of metal oxyhydroxide under anoxic conditions, diffusive $\mathrm{PO}_{4}$ fluxes from sediments. However in estuaries, the impact of microbiological activity on $\mathrm{P}$ mineralization is rarely investigated. The aim of this study was to highlight evidence of organic $\mathrm{P}$ microbial mineralization in two macrotidal estuaries. This microbial enzymatic process, occurring via the activity of alkaline phosphatases (AP), could be an additionnal contribution to $\mathrm{PO}_{4}$ regeneration in estuaries. In this article, we actually present observations of high potential APA in estuarine waters supporting $\mathrm{PO}_{4}$ concentrations largely above the threshold known for the repression of AP synthesis. In spring and summer, this high potential APA corresponds to an estuarine production of $\mathrm{PO}_{4}$ in the oligohaline part of the estuaries. These results will be compared with the few measurements of APA already done in estuaries. Then, we will analyze which are the microorganisms capable of inducing $\mathrm{AP}$ synthesis in $\mathrm{PO}_{4}$-rich waters. Finally we will discuss the potential contribution of the microbial mineralization to the $\mathrm{PO}_{4}$ estuarine production. 

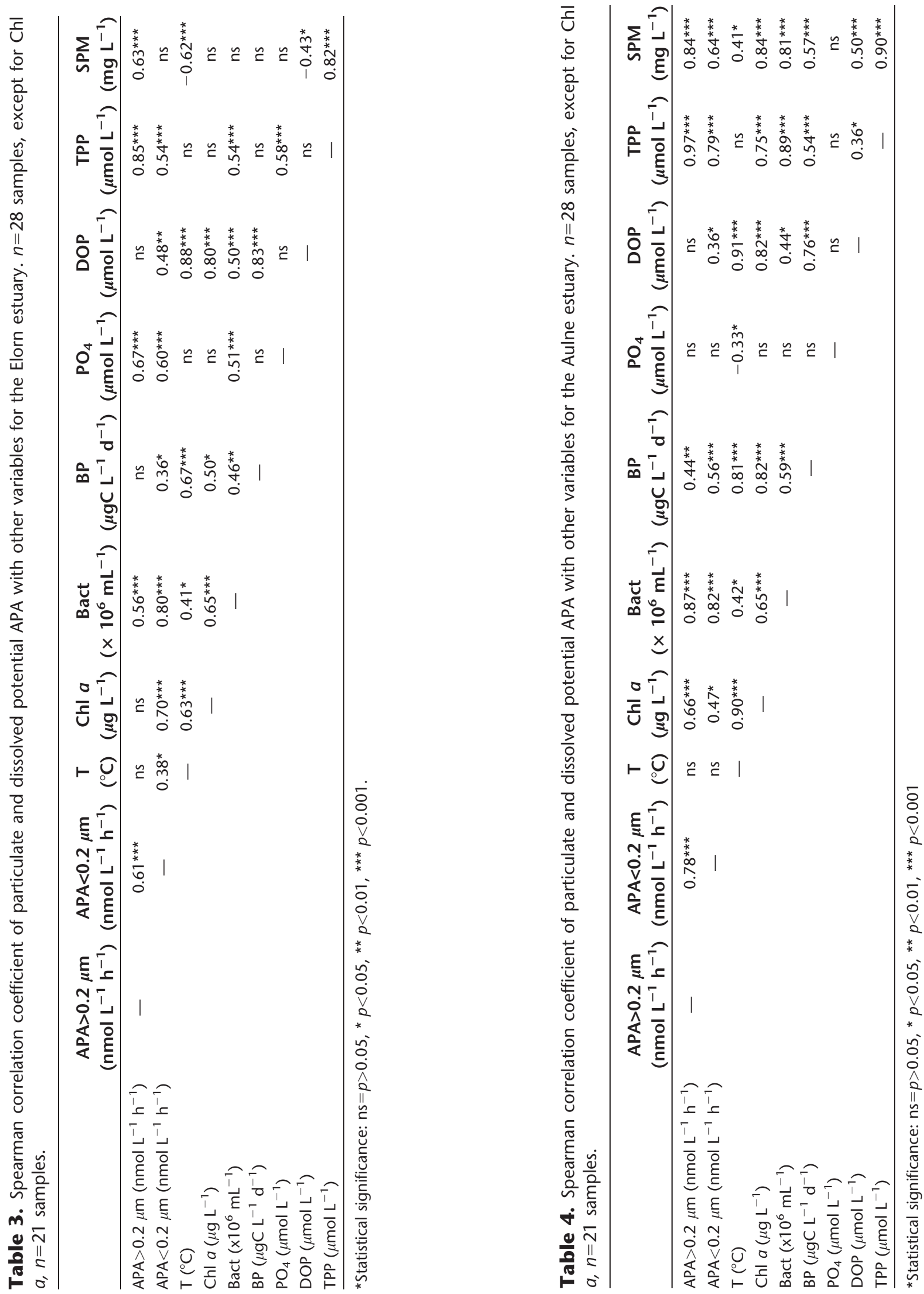

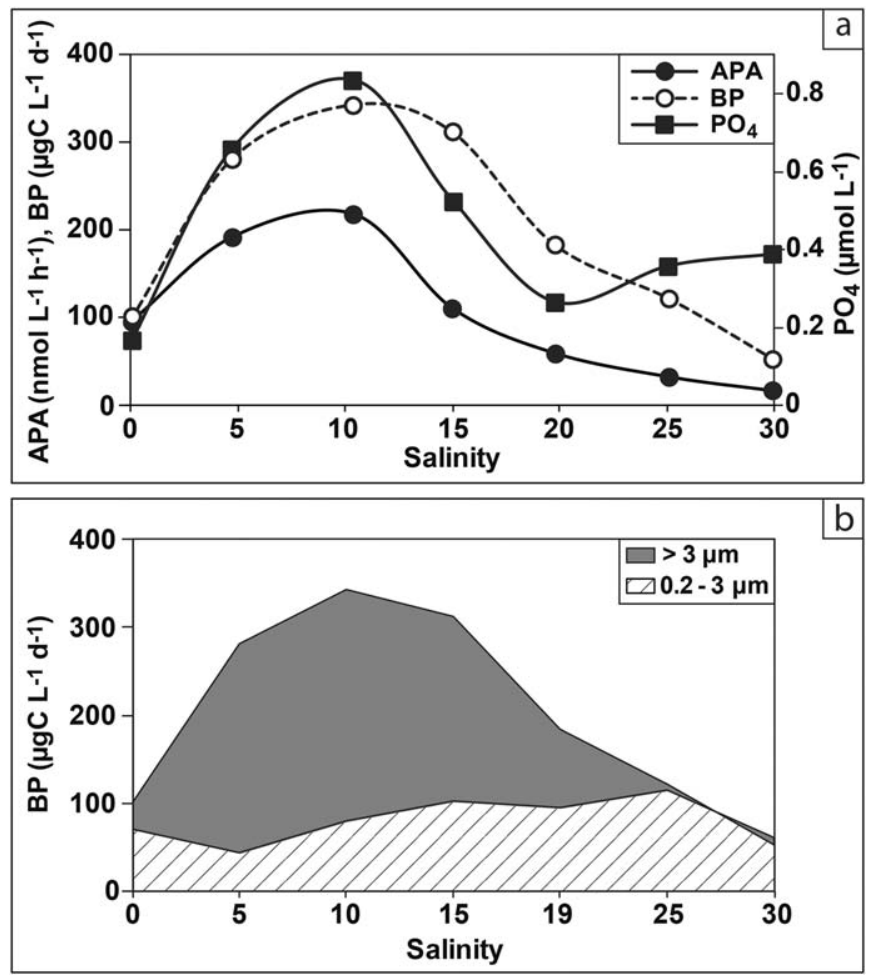

Fig. 5. (a) Total potential APA, bacterial production (BP), phosphate $\left(\mathrm{PO}_{4}\right)$ and $(\mathrm{b})$ size-fractionated $\mathrm{BP}$ in the salinity gradient of the Aulne estuary in July 2009.

\section{Deficit of APA studies in estuaries}

Few studies have investigated APA in estuaries. As a consequence, the production of $\mathrm{PO}_{4}$ by microbial mineralization of organic $\mathrm{P}$ has never been considered as a potential source of $\mathrm{PO}_{4}$ in estuaries. One reason is the fact that riverine $\mathrm{P}$ entering estuaries is considered to originate from weathered continental rocks and soils (Ruttenberg 2003). It follows logically that the main processes governing $\mathrm{PO}_{4}$ regeneration in estuaries are those concerning the mineral particulate phases of $\mathrm{PO}_{4}$ (adsorption/desorption of $\mathrm{PO}_{4}$, release of $\mathrm{PO}_{4}$ from the reduction of metal oxyhydroxide, ...). It has been widely shown that these processes actually explain part of the partitioning between the different P species (Conley et al. 1995; Deborde et al. 2007; Van der Zee et al. 2007). However biological processes have largely been ignored. To explore further the mechanisms underlying $\mathrm{P}$ speciation during mixing between river water and seawater, some studies have combined field observations and laboratory experiments (Lin et al. 2012). However, some estuarine mixing experiments have been conducted at low temperature $\left(4^{\circ} \mathrm{C}\right)$, which obviously underestimated biological mechanisms. Hence, the partitioning of $\mathrm{P}$ between inorganic, organic, dissolved, and particulate has mainly been addressed from a geochemical point of view.

The usual regulation scheme of APA by $\mathrm{PO}_{4}$ is the second reason why APA has not been investigated in $\mathrm{PO}_{4}$-rich estua- ries. Indeed, it is well documented that AP synthesis is repressed by $\mathrm{PO}_{4}$, which is the end product derived from the substrate of the enzyme (Chrost 1991). More precisely, AP synthesis is regulated by intracellular $\mathrm{PO}_{4}$ levels in microorganisms, which depends on ambient $\mathrm{PO}_{4}$ concentrations (Gage and Gorham 1985). Alkaline phosphatase synthesis is induced when low recurrent $\mathrm{PO}_{4}$ concentrations have affected intracellular P and, conversely, is repressed when the intracellular P pool has filled up (Perry 1976; Chrost 1991). In environments supporting seasonal P limitation of micro-organism growth, an inverse hyperbolic relationship has been found between potential APA and $\mathrm{PO}_{4}$ with a transition between high $\left(>20 \mathrm{nmol} \mathrm{L}^{-1} \mathrm{~h}^{-1}\right)$ and low activities $\left(<10 \mathrm{nmol} \mathrm{L}{ }^{-1}\right.$ $\mathrm{h}^{-1}$ ) usually occurring at $0.05-0.1 \mu \mathrm{mol} \mathrm{L}^{-1}$ (Siuda and Chrost 1987; Nausch 1998; Labry et al. 2005). This threshold is also relevant for specific (i.e., normalized to biomass) phytoplankton and bacterial APA, free bacteria dominating the bacterial community in these P-limited environments (Labry et al. 2005). In estuaries, $\mathrm{PO}_{4}$ concentrations are largely above this threshold for the induction/repression of enzyme production. This is the case in the present study, $\mathrm{PO}_{4}$ concentrations being higher than 0.16 and $0.48 \mu \mathrm{mol} \mathrm{L}^{-1}$, in the Aulne and Elorn estuaries, respectively. Thus, very low APA $(<10 \mathrm{nmol}$ $\left.\mathrm{L}^{-1} \mathrm{~h}^{-1}\right)$ is expected to occur.

\section{Unexpected high potential APA in estuaries}

The APA results from the Aulne and Elorn estuaries exhibit very high values in the present study. Total potential APA ranges between $50 \mathrm{nmol} \mathrm{L}{ }^{-1} \mathrm{~h}^{-1}$ and $506 \mathrm{nmol} \mathrm{L}^{-1} \mathrm{~h}^{-1}$ in the low salinity part of the estuaries for relative $\mathrm{PO}_{4}$-rich waters $\left(>0.26 \mu \mathrm{mol} \mathrm{L}^{-1}\right)$. A few studies dealing with APA in estuaries have been done. In the Lower Elbe estuary, Karrasch et al. (2003) found a maximum value for $V_{\mathrm{m}}$ at $45 \mu \mathrm{g}$

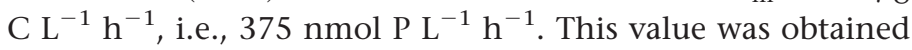
by incubation in the dark at in situ temperature (in autumn) and with $1000 \mu \mathrm{mol} \mathrm{L}{ }^{-1}$ MUF-P. Using a saturating concentration of $50 \mu \mathrm{mol} \mathrm{L}^{-1}$ MUF-P, Hernández et al. (2000) also found total $V_{\mathrm{m}}$ frequently above $50 \mathrm{nmol} \mathrm{L} \mathrm{L}^{-1} \mathrm{~h}^{-1}$, and up to $490 \mathrm{nmol} \mathrm{L}{ }^{-1} \mathrm{~h}^{-1}$ in Mediterranean estuarine waters supporting more than $0.9 \mu \mathrm{mol} \mathrm{L}{ }^{-1} \mathrm{PO}_{4}$. They measured APA using a pH 8.3 buffered medium, and a constant incubation temperature $\left(20^{\circ} \mathrm{C}\right)$ whatever the season. Similarly, Huber et al. (1985), measuring APA after incubation at $25^{\circ} \mathrm{C}, \mathrm{pH} 7.5$ and using a colorimetric method, found total $V_{\mathrm{m}}$ between $203 \mathrm{nmol} \mathrm{L}{ }^{-1} \mathrm{~h}^{-1}$ and $568 \mathrm{nmol} \mathrm{L}^{-1} \mathrm{~h}^{-1}$ in a shallow Australian estuary within a range of $\mathrm{PO}_{4}$ between $0.21 \mu \mathrm{mol} \mathrm{L} \mathrm{L}^{-1}$ and $0.39 \mu \mathrm{mol} \mathrm{L}{ }^{-1}$. All these potential APA values, including our results, are consistent in spite of methodological differences and very different geographical locations (from North Sea to Australian waters). Consequently, the high levels of potential APA found in all these studies support the idea that the mineralization of organic P via APA may be a process shared by several estuaries. 

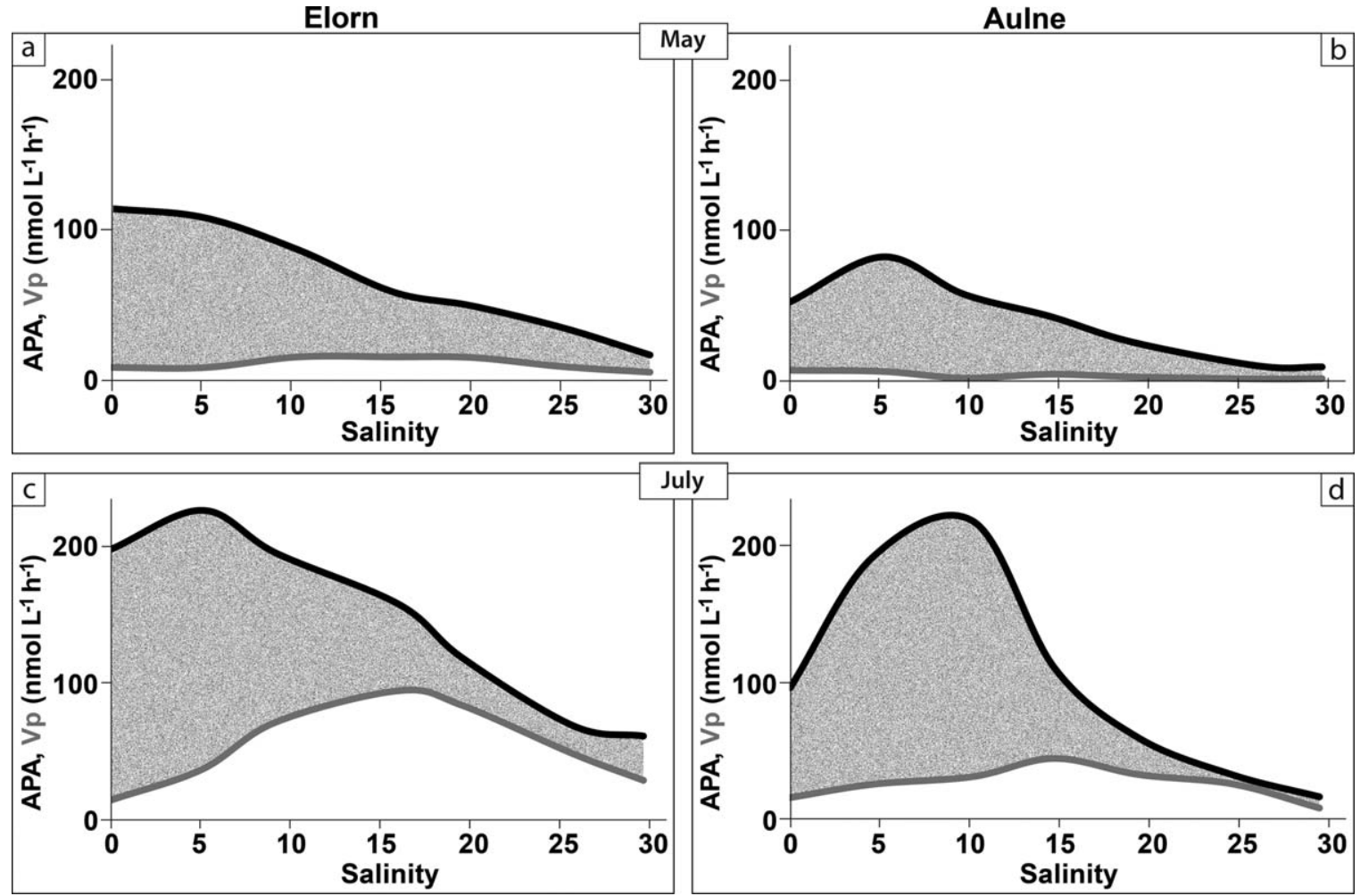

Fig. 6. Total potential APA (dark line above) and phosphate uptake rates ( $V_{p}$, grey line below) in the salinity gradient of the Elorn (left) and Aulne (right) estuaries in May $(a, b)$ and July $(c, d) 2009$. The shaded area between potential APA and $V_{p}$ represents the area of possibilities for net production rate of phosphate via microbial remineralization.

\section{Controlling factors of APA in estuaries}

\section{Regulation of alkaline phosphatase synthesis}

As most of the ectoenzymes synthesized by aquatic microorganisms are mainly inducible, the induction and repression of ectoenzyme synthesis are regulated by substrates and/or end-products derived from the substrates (Chrost 1990). As suggested above, the induction and repression of alkaline phosphatase synthesis by $\mathrm{PO}_{4}$ is a particularly well documented example of enzyme regulation. However, in the present study, no inverse hyperbolic relationship has been observed between potential APA and $\mathrm{PO}_{4}$. Potential APA is either positively related to $\mathrm{PO}_{4}$ or not correlated with $\mathrm{PO}_{4}$. Potential APA is rather strongly correlated to TPP, and more largely to SPM in both the Aulne and Elorn estuaries. The highest value of APA in the Lower Elbe estuary was also associated with the maximum concentration of particles (Karrasch et al. 2003). Kim et al. (2007) found that particulate APA was positively correlated with particulate $\mathrm{P}$ and with $\mathrm{PO}_{4}$ in the benthic nepheloid layer of a large mesotrophic lake. A relationship between APA and SPM has also been found in the overlying water column of sediment cores after the resuspension of surficial sediments (Newman and Reddy 1992). It appears that APA is rather regulated by their substrates, e.g., compounds of the particulate organic phosphorus pool, than by the end-product $\left(\mathrm{PO}_{4}\right)$ in the present study. This is consistent with the highly significant correlations found between particulate, or dissolved APA, and particulate organic phosphorus $(p<0.001$, Spearman correlation coefficient $r=0.95$, and 0.77 for the Aulne estuary, $r=0.76$, and 0.66 for the Elorn estuary, respectively). However the mode of regulation is strongly linked to the micro-organisms responsible for the synthesis of AP.

\section{Micro-organisms contributing to APA in estuaries}

Alkaline phosphatases are known to be synthesized both by bacteria and phytoplankton. It has been widely demonstrated that phytoplankton AP is mainly inducible, being actively synthesized when $P$ is depleted and repressed when $P$ is replete. It was evidenced both in the field, in environments supporting seasonal P limitation (Gage and Gorham 1985; Chrost and Overbeck 1987; Labry et al. 2005), and in cultures (Perry 1976; Cembella et al. 1984; Jauzein et al. 2010). In $\mathrm{PO}_{4}$-rich estuaries, phytoplankton APA is expected to be low and do not contribute significantly to the high $>1 \mu \mathrm{m}$ APA in the present study. In addition, the significant contribution of Pheo, except in July in the Elorn estuary, seems to indicate a significant part of altered phytoplankton cells. Senescent cells are important loci for colonizing bacteria, which could explain the relation between 
particulate potential APA and Chl $a$ in the Aulne estuary. In P-limited environments, where free bacteria dominate bacterial community, bacterial APA was also found to be regulated by $\mathrm{PO}_{4}$ availability (Labry et al. 2005). Free bacterial APA may have been repressed by $\mathrm{PO}_{4}$ in the present study. In any case, free bacterial APA (in the $0.2-1 \mu \mathrm{m}$ fraction) was the lowest contributor to total APA, its contribution throughout the survey for both estuaries reaching 5-18\% of total APA only. By contrast, $>1 \mu \mathrm{m}$ APA contributed significantly to total APA and sometimes even dominated. This high $>1 \mu \mathrm{m}$ APA is very likely due to particle-attached bacteria. This is consistent with the strong correlation between particulate potential APA and bacterial biomass, and the close relationship between the production of attached bacteria and potential APA. This is also supported by the high contributions (20-85\%) of particle-attached bacteria production to total production at the peak of the maximum potential APA, when size-fractionation was carried out. These are minimum contributions of particle-attached bacteria to total production, since bacteria attached to particles $<3 \mu \mathrm{m}$ may have passed through $3 \mu \mathrm{m}$ filters.

\section{High potential APA of particle-attached bacteria}

Following this, particle-attached bacteria are suspected to be the main contributors to the high potential APA observed in the Aulne and Elorn estuarine waters. The importance of particle-attached bacteria, in the occurrence of high APA, has already been reported in zones of particulate matter accumulation, such as aggregates in mesopelagic marine (Smith et al. 1992; Zoppini et al. 2005) and lake environment (Grossart and Simon 1998) or in benthic nepheloid layers of aquatic environment (Kim et al. 2007). It has been shown that bacterial hydrolytic enzyme activities (APA, protease, $\beta$-glucosidase,...) were higher in aggregated particles, than in surrounding waters (Karner and Herndl 1992; Smith et al. 1992; Martinez et al. 1996; Grossart and Simon 1998). As glucosidase and protease are synthesized by bacteria only, specific activities have been calculated for both free and attached bacteria. Particle-attached bacteria have displayed higher specific activities in terms of per cell rates (Karner and Herndl 1992) or per $\mu \mathrm{g} C$ rate (Middelboe et al. 1995) than free bacteria. In the absence of reliable counts of free and particle-attached bacteria, we cannot calculate specific APA of free and attached bacteria in our study. However, as demonstrated for glucosidase and protease in aggregated particles, we hypothesize that the high particulate potential APA observed in the present study, which is highly correlated to particles (TPP and SPM) and bacterial biomass, is mainly due to high specific APA of particle-attached bacteria. Total specific bacterial APA (total particulate APA divided by total bacteria count) can be calculated with our dataset, and the values obtained are in the range of values (8-113 and 4-26 pmol per $10^{6}$ cells $\mathrm{h}^{-1}$ for Elorn and Aulne estuaries, respectively) already reported for severely P-limited free bacteria of coastal waters (1-99 pmol per $10^{6}$ cells $\mathrm{h}^{-1}$, Labry et al. 2005). This supports the hypothesis that particulate $\mathrm{AP}$, in the present study are predominantly synthesized by bacteria, and showed that specific APA of non P-limited estuarine bacteria could be in the same order of magnitude than specific APA of severely P-limited coastal free bacteria.

For bacteria, the mechanisms of APA regulation are more complicated than those for phytoplankton. The hydrolysis of organic P compounds liberates an organic carbon moiety, which could also be composed of nitrogen. After the hydrolytic detachment of $\mathrm{PO}_{4}$, this moiety could be more directly utilizable by bacteria. Thus phosphorus, carbon, or nitrogen availability could drive induction or repression of phosphatase synthesis (Hoppe 2003, Steenbergh et al. 2011). Particulate organic carbon reached high concentrations in rivers and the oligohaline waters of both estuaries in the present study (54-1051 $\mu \mathrm{M}$, S. L'helguen pers. comm.). High levels of dissolved organic carbon have already been reported in the Elorn estuary (100-350 $\mu \mathrm{M}$, Aminot et al. 1990). In addition the Aulne and Elorn river waters are known to be highly fertilized in nitrogen, mostly nitrate, by agriculture activity (in the range 282-655 $\mu \mathrm{M}$ in the present study, J. F. Maguer pers. comm.). Although a carbon limitation of bacteria may lead to the induction of AP synthesis in deep waters of mesopelagic environment (Hoppe and Ullrich 1999), it is unlikely that phosphorus, carbon, or nitrogen limitation of bacteria may have occurred in estuaries receiving continuous input of organic matter from land. Instead, the attachment of bacteria to particulate organic matter, e.g., to the substrates of $\mathrm{AP}$, is probably an important factor in the induction of AP synthesis. It creates a close proximity between enzyme substrates and the particulate enzyme complex. As a result, particle-attached bacteria would develop an enzymatic machinery to degrade organic matter whatever their phosphorus, carbon or nitrogen demand. This is consistent with the findings that only a little part of the hydrolysates produced by the intense hydrolytic enzyme activity in aggregated particles is taken up by attached bacteria, which conducts to an enrichment of the surrounding waters in hydrolysates (Smith et al. 1992; Grossart and Simon 1998).

\section{Other origins for high APA in estuaries}

Accordingly, we presume that APA in estuaries is regulated by the amount of particulate organic $\mathrm{P}$ compounds as substrates of AP, and by the attachment of bacteria to particles, the starting point of an enzymatic synthesis cascade to degrade organic matter. To a lesser extent, the adsorption of extracellular AP onto mineral surfaces, and the modifications of activity induced by their interactions may have contributed to high particulate potential APA in the Aulne and Elorn estuaries. Alkaline phosphatases, as proteins, have a strong affinity to solid surfaces. The adsorption of enzymes on mineral surfaces, such as clay minerals, is a complex phenomenon, involving numerous interactions such as 
concentration of substrate, complexation of enzymes with humic acids, changes in protein conformation and stabilization, and protection from photodegradation (Tietjen and Wetzel 2003; Quiquampoix and Mousain 2005). The activity of AP is ultimately positively or negatively modified.

Finally, we also found significant dissolved activities in the present study. Given the high correlations between dissolved potential APA and bacterial biomass, dissolved APA may also have originated from enzymes produced by particle-attached bacteria and liberated into the dissolved phase. Since APA of particle-attached bacteria seems to be regulated by particulate organic $\mathrm{P}$ compounds, this would explain the correlation between dissolved APA and TPP, particularly POP (see above in the Discussion section). To a lesser extent, phytoplankton may also have contributed, through the release of intracellular enzymes induced by haline stress, leading to cell lysis, and by zooplankton grazing on phytoplankton bloom. This could explain the correlation between dissolved APA and Chl $a$ in both estuaries.

Hence, the results of the present study suggest that particle-attached bacteria are mainly responsible for high potential APA in estuaries. The attachment of bacteria to estuarine particles and the close proximity of bacterial enzymes to particulate organic $\mathrm{P}$ compounds would drive the induction of alkaline phosphatase synthesis.

\section{APA contribution to $\mathrm{PO}_{4}$ estuarine production}

Since the uptake rates of $\mathrm{PO}_{4}$ were estimated in May and July, we can superimpose, on the same figure, actual $\mathrm{PO}_{4}$ uptake rates $(\mathrm{Vp})$ and total potential APA for both estuaries (Fig. 6). The shaded areas represent the area of possibilities for the net production rate of $\mathrm{PO}_{4}$ via microbial remineralization. It appears clearly that the highest potential of net production rates of $\mathrm{PO}_{4}$ occurs in the low salinity part of estuaries (salinity $<15$ ) where particle concentrations are the highest (maximum turbidity zone). In this oligohaline zone, potential APA is 6-29 times higher than the $\mathrm{PO}_{4}$ uptake rates, whereas potential APA is only 2-6 times higher in the downstream part of the estuaries. Even if actual APA represents only a few percent of potential APA, as it was estimated elsewhere (Labry et al. 2005), the pattern is still working and is favorable to a biological production of $\mathrm{PO}_{4}$ in the oligohaline zone of estuaries in spring and summer.

Non-biological mechanisms contribute doubtless to the $\mathrm{PO}_{4}$ enrichment of estuarine waters. First of all, $\mathrm{PO}_{4}$ is desorbed from freshwater particles at the boundary between fresh and saline waters due to the high ionic strength of saline waters. This process is particularly relevant in the oligohaline part (5-15) of many estuaries such as the Gironde and the Seine (Deborde et al. 2007; Nemery and Garnier 2007). However, the strongest SPM and TPP inflows (in February and November), for both the Elorn and Aulne rivers, were not followed by a $\mathrm{PO}_{4}$ production in the oligohaline waters. This suggests that desorption may not constitute the major process for the production of $\mathrm{PO}_{4}$ in the oligohaline waters. Secondly, diffusive $\mathrm{PO}_{4}$ fluxes at the sediment water interface may be enhanced in spring and summer, as the sediment becomes anoxic, which increases the release of $\mathrm{PO}_{4}$ from the reduction of Fe(III)-bound-P (Ruttenberg 2003; Andrieux-Loyer et al. 2008). Diffusive $\mathrm{PO}_{4}$ fluxes were estimated in spring and summer 2009. Even if they were locally variable, they were higher upstream of estuaries (spring and summer values reached 25-100 $\mu \mathrm{mol} \mathrm{m} \mathrm{m}^{-2} \mathrm{~d}^{-1}$ and $0-290$ $\mu \mathrm{mol} \mathrm{m} \mathrm{m}^{-2} \mathrm{~d}^{-1}$ in the Aulne and Elorn estuary, respectively) than downstream (20-50 $\mu \mathrm{mol} \mathrm{m} \mathrm{m}^{-2} \mathrm{~d}^{-1}$ for both estuaries, F. Andrieux-Loyer pers. comm.). Therefore, estuarine waters were enriched in $\mathrm{PO}_{4}$ by diffusion from the sediment. In addition, the resuspension of sediment driven by tide and river runoff can also stimulate adsorption/desorption processes, as well as it can induce an enhancement of APA linked to resuspended sediment attached bacteria under oxic conditions (Newman and Reddy 1992; Kim et al 2007). However the precise contribution of diffusion and periodic sediment resuspension in the $\mathrm{PO}_{4}$ concentration of the oligohaline part (salinity 5-15) of estuaries needs extensive measurements.

Thus, numerous processes can explain an estuarine production of $\mathrm{PO}_{4}$. But it is the first time a relationship between microbial activity and $\mathrm{PO}_{4}$ production is suggested. The accurate contribution of this biological production to total $\mathrm{PO}_{4}$ production remains, however, unknown. Laboratory experiments of particulate organic matter decomposition and $\mathrm{PO}_{4}$ regeneration via APA remain to be done. This is the next step to go further in the estimation of the impact of microbial mineralization in the P cycle.

Finally, as a result of the complexity and variability of processes in estuaries, at both temporal and spatial scales, only a final integration of the processes in a modeling approach will be able to specify the importance of the different $\mathrm{PO}_{4}$ sources and fluxes in the budget of estuaries.

\section{Conclusion}

The present study highlights the high levels of potential APA in two macrotidal estuaries having $\mathrm{PO}_{4}$ concentrations largely above the common threshold known for the induction/repression of AP synthesis. These estuaries have different $\mathrm{PO}_{4}$ concentrations $\left(\mathrm{PO}_{4}\right.$ was $1.5-5$ times lower in the Aulne than in the Elorn estuary) and different morphologies and hydrodynamics, which impacts on the residence time of water and particles. Despite these differences and the high variability in micro-organism dynamics obviously occurring in estuaries (i.e., variable SPM linked to complex hydrodynamics, occurrence of phytoplankton bloom), potential APA were similarly high, suggesting that the mineralization of organic P via APA is a process shared by several estuaries. APA is obviously not regulated by $\mathrm{PO}_{4}$ but is closely related to TPP and bacterial biomass. In addition, the close 
evolution of potential APA and production of particleattached bacteria in summer and autumn suggest that AP are synthesized by particle-attached bacteria and probably hydrolyze particulate organic $\mathrm{P}$ compounds. These results imply that the production of $\mathrm{PO}_{4}$ by the microbial mineralization of particulate organic phosphorus is a process to be taken into account in $\mathrm{PO}_{4}$ regeneration in estuaries, besides physicochemical processes. This production contributes to the delivery of $\mathrm{PO}_{4}$ to adjacent coastal waters, ultimately influencing which nutrient may limit primary production. This study is the first to emphasize the role of enzymatic activity in the speciation of $\mathrm{P}$ in estuaries. Further investigations need to be conducted to precise the contribution of biological activity in $\mathrm{P}$ cycle and to evaluate if the findings of this article could actually be broadened to other estuaries.

\section{References}

Aminot, A., M. A. El-Sayed, and R. Kerouel. 1990. Fate of natural and anthropogenic dissolved organic carbon in the macrotidal Elorn estuary (France). Mar. Chem. 29: 255-275. doi:10.1016/0304-4203(90)90017-7

Aminot, A., and R. Kérouel. 2001. An automated photooxidation method for the determination of dissolved organic phosphorus in marine and fresh water. Mar. Chem. 76: 113-126. doi:10.1016/S0304-4203(01)00052-4

Aminot, A., R. Kérouel, and S. C. Coverly. 2009. Nutrients in seawater using segmented flow analysis, p. 143-178. In O. Wurl [ed.], Practical guidelines for the analysis of seawater. CRC Press.

Ammerman, J. W. 1993. Microbial cycling of inorganic and organic phosphorus in the water column, p. 649-659. In P. F. Kemp, B. F. Sherr, E. B. Sherr, and J. J. Cole [eds.], Handbook of methods in aquatic microbial ecology. Lewis Publishers.

Andrieux-Loyer, F., X. Philippon, G. Bally, R. Kérouel, A. Youenou, and J. Le Grand. 2008. Phosphorus dynamics and bioavailability in sediments of the Penzé Estuary (NW France): In relation to annual P-fluxes and occurrences of Alexandrium minutum. Biogeochemistry 88: 213-231. doi:10.1007/s10533-008-9199-2

Berman, T. 1970. Alkaline phosphatases and phosphorus availability in Lake Kinneret. Limnol. Oceanogr. 15: 663674. doi:10.4319/1o.1970.15.5.0663

Cai, Y., and L. Guo. 2009. Abundance and variation of colloidal organic phosphorus in riverine, estuarine and coastal waters in the northern Gulf of Mexico. Limnol. Oceanogr. 54: 1393-1402. doi:10.4319/lo.2009.54.4.1393

Cembella, A. D., N. J. Antia, and P. J. Harrison. 1984. The utilization of inorganic and organic phosphorus compounds as nutrients by eukaryotic microalgae: A multidisciplinary perspective: Part 1. CRC. Crit. Rev. Microb. 10: 317-391. doi:10.3109/10408418209113567

Chrost, R. J. 1990. Microbial ectoenzymes in aquatic environments, p. 47-78. In J. Overbeck and R. J. Chrost [eds.],
Aquatic microbial ecology: biochemical and molecular approaches. Springer-Verlag.

Chrost, R. J. 1991. Environmental control of the synthesis and activity of aquatic microbial ectoenzymes, p. 29-59. In R. J. Chrost [ed.], Microbial enzymes in aquatic environments. Springer-Verlag.

Chrost, R. J., and H. J. Krambeck. 1986. Fluorescence correction for measurements of enzyme activity in natural waters using methylumbelliferyl-substrates. Arch. Hydrobiol. 106: 79-90.

Chrost, R. J., and J. Overbeck. 1987. Kinetics of alkaline phosphatase activity and phosphorus availability for phytoplankton and bacterioplankton in Lake Plußsee (North German eutrophic lake). Microb. Ecol. 13: 229-248. doi: 10.1007/BF02025000][24213298

Conley, D. J., W. M. Smith, J. C. Cornwell, and T. R. Fisher. 1995. Transformation of particle-bound phosphorus at the land-sea interface. Estuarine Coastal Shelf Sci. 40: 161-176. doi:10.1016/S0272-7714(05)80003-4

Crump, B. C., and J. A. Baross. 1996. Particle-attached bacteria and heterotrophic plankton associated with the Columbia River estuarine turbidity maxima. Mar. Ecol. Prog. Ser. 138: 265-273. doi:10.3354/meps138265

Deborde, J., P. Anschutz, G. Chaillou, H. Etcheber, M. V. Commarieu, P. Lecroart, and G. Abril. 2007. The dynamics of phosphorus in turbid estuarine systems: Example of the Gironde estuary (France). Limnol. Oceanogr. 52: 862872. doi:10.4319/10.2007.52.2.0862

Delmas, D., C. Legrand, C. Bechemin, and C. Collinot. 1994. Exoproteolytic activity determined by flow injection analysis: Its potential importance for bacterial growth in coastal marine pond. Aquat. Living Resour. 7: 17-24. doi: 10.1051/alr:1994003

Dyhrman, S. 2005. Ectoenzymes in Prorocentrum minimum. Harmful Algae 4: 619-627. doi:10.1016/j.hal.2004.08.011

Etcheber, H., A. Taillez, G. Abril, J. Garnier, P. Servais, F. Moatar, and M. C. Commarieu. 2007. Particulate organic carbon in the estuarine turbidity maxima of the Gironde, Loire and Seine estuaries: Origin and lability. Hydrobiologia 588: 245-259. doi:10.1007/s10750-007-0667-9

Fang, T. H. 2000. Partitioning and behaviour of different forms of phosphorus in the Tanshui estuary and one of its tributaries, Northern Taiwan. Estuarine Coastal Shelf Sci. 50: 689-701. doi:10.1006/ecss.1999.0604

Froelich, P. N. 1988. Kinetic control of dissolved phosphate in natural rivers and estuaries: A primer on the phosphate buffer mechanism. Limnol. Oceanogr. 33: 649-668. doi: 10.4319/1o.1988.33.4_part_2.0649

Fuhrman, J. A., and F. Azam. 1982. Thymidine incorporation as a measure of heterotrophic bacterioplankton production in marine surface waters: evaluation and field results. Mar. Biol. 66: 109-120. doi:10.1007/BF00397184

Gage, M. A., and E. Gorham. 1985. Alkaline phosphatase activity and cellular phosphorus as an index of the 
phosphorus status of phytoplankton in Minnesota lakes. Fresh. Biol. 15: 227-233. doi:10.1111/j.13652427.1985.tb00195.X

Garnier, J., G. Billen, S. Even, H. Etcheber, and P. Servais P. 2008. Organic matter dynamics and budgets in the turbidity maximum zone of the Seine Estuary (France). Estuarine Coastal Shelf Sci. 77: 150-162. doi:10.1016/ j.ecss.2007.09.019

Grossart, H. P., and M. Simon. 1998. Bacterial colonization and microbial decomposition of limnetic organic aggregates (lake snow). Aquat. Microb. Ecol. 15: 127-140. doi: 10.3354/ame015127

Hernández, I., A. Pérez-Pastor, and J. Lucas Pérez Lloréns. 2000. Ecological significance of phosphomonoesters and phosphomonoesterase activity in a small Mediterranean river and its estuary. Aquat. Ecol. 34: 107-117. doi: 10.1023/A:1009930405572

Holm-Hansen, O., C. J. Lorenzen, R. W. Holmes, and J. D. H. Strickland. 1965. Fluorometric determination of chlorophyll. J. Cons. Perm. Int. Explor. Mer 30: 3-15. doi: 10.1093/icesjms/30.1.3

Hoppe, H. G. 1983. Significance of exoenzymatic activities in the ecology of brackish water: measurements by means of methylumbelliferyl-substrates. Mar. Ecol. Prog. Ser. 11: 299-308. doi:10.3354/meps011299

Hoppe, H. G. 2003. Phosphatase activity in the sea. Hydrobiologia 493: 187-200. doi:10.1023/A:1025453918247

Hoppe, H. G., and S. Ullrich. 1999. Profiles of ectoenzymes in the Indian Ocean: phenomena of phosphatase activity in the mesopelagic zone. Aquat. Microb. Ecol. 19: 139148. doi:10.3354/ame019139

Huber, A. L., J. O. Gabrielson, and D. K. Kidby. 1985. Phosphatase activities in the waters of a shallow estuary, Western Australia. Estuarine Coastal Shelf Sci. 21: 567-576. doi:10.1016/0272-7714(85)90057-5

Jauzein, C., C. Labry, A. Youenou, J. Quéré, D. Delmas, and Y. Collos. 2010. Growth and phosphorus uptake by the toxic dinoflagellate Alexandrium catenella (Dinophyceae) in response to phosphate limitation. J. Phycol. 46: 926936. doi:10.1111/j.1529-8817.2010.00878.x

Karner, M., and G. J. Herndl. 1992. Extracellular enzymatic activity and secondary production in free-living and marine-snow-associated bacteria. Mar. Biol. 113: 341-347. doi:10.1007/BF00347289

Karrasch, B., S. Ullrich, M. Mehrensa, and H. ZimmermannTimm. 2003. Free and particle-associated extracellular enzyme activity and bacterial production in the lower Elbe estuary, Germany. Acta hydrochim. Hydrobiol. 31: 297-306. doi:10.1002/aheh.200300505

Kim, C., Y. Nishimura, and T. Nagata. 2007. High potential activity of alkaline phosphatase in the benthic nepheloid layer of a large mesotrophic lake: Implications for phosphorus regeneration in oxygenated hypolimnion. Aquat. Microb. Ecol. 49: 303-311. doi:10.3354/ame01137
Labry, C., D. Delmas, and A. Herbland. 2005. Phytoplankton and bacterial alkaline phosphatase activities in relation to phosphate and DOP availability within the Gironde plume waters (Bay of Biscay). J. Exp. Mar. Biol. Ecol. 318: 213-225. doi:10.1016/j.jembe.2004.12.017

Labry, C., A. Youenou, D. Delmas, and P. Michelon. 2013. Addressing the measurement of particulate organic and inorganic phosphorus in estuarine and coastal waters. Continental Shelf Res. 60: 28-37. doi:10.1016/ j.csr.2013.04.019

Li, H., M. J. W. Veldhuis, and A. F. Post. 1998. Alkaline phosphatase activities among planktonic communities in the northern Red Sea. Mar. Ecol. Prog. Ser. 173: 107-115. doi:10.3354/meps173107

Lin, P., Chen, M., and L. Guo. 2012. Speciation and transformation of phosphorus and its mixing behavior in the Bay of St. Louis estuary in the northern Gulf of Mexico. Geochim Cosmochim Acta 87: 283-298. doi:10.1016/ j.gca.2012.03.040

Martinez, J., and F. Azam. 1993. Periplasmic aminopeptidase and alkaline phosphatase activities in a marine bacterium: Implications for substrate processing in the sea. Mar. Ecol. Prog. Ser. 92: 89-97. doi:10.3354/meps092089

Martinez, J., D. C. Smith, G. F. Steward, and F. Azam. 1996. Variability in ectohydrolytic enzyme activities of pelagic marine bacteria and its significance for substrate processing in the sea. Aquat. Microb. Ecol. 10: 223-230. doi: 10.3354/ame010223

Middelboe, M., M. Sondergaard, Y. Letarte, and N. H. Borch. 1995. Attached and free-living bacteria: Production and polymer hydrolysis during a diatom bloom. Microb. Ecol. 29: 231-248. doi:10.1007/BF00164887

Murphy, J., and J. P. Riley. 1962. A modified single solution method for the determination of phosphate in natural waters. Anal. Chim. Acta 27: 31-36. doi:10.1016/S00032670(00)88444-5

Nausch, M. 1998. Alkaline phosphatase activities and the relationship to inorganic phosphate in the Pomeranian Bight (southern Baltic Sea). Aquat. Microb. Ecol. 16: 8794. doi:10.3354/ame016087

Nemery, J., and J. Garnier. 2007. Typical features of particulate phosphorus in the Seine estuary (France). Hydrobiologia 588: 271-290. doi:10.1007/s10750-007-0670-1

Newman, S., and K. R. Reddy. 1992. Sediment resuspension effects on alkaline phosphatase activity. Hydrobiologia 245: 75-86. doi:10.1007/BF00764767

Perry, M. J. 1976. Phosphate utilization by an oceanic diatom in phosphorus limited chemostat culture and in the oligotrophic waters of the Central North Pacific Ocean. Limnol. Oceanogr. 21: 88-107. doi:10.4319/lo.1976.21.1.0088

Ploug, H., H. Zimmermann-Timm, and B. Schweitzer. 2002. Microbial communities and respiration on aggregates in the Elbe Estuary, Germany. Aquat. Microb. Ecol. 27: 241248. doi:10.3354/ame027241 
Porter, K. G., and Y. S. Feig. 1980. The use of DAPI for identifying and counting aquatic microflora. Limnol. Oceanogr. 25: 943-948. doi:10.4319/1o.1980.25.5.0943

Prastka, K., R. Sanders, and T. Jickells. 1998. Has the role of estuaries as sources or sinks of dissolved inorganic phosphorus changed over time? Results of a Kd study. Mar. Poll. Bull. 36: 718-728. doi:10.1016/S0025-326X(98)00052-6

Quiquampoix, H., and D. Mousain. 2005. Enzymatic hydrolysis of organic phosphorus, p. 89-112. In B. L. Turner, E. Frossard, and D. S. Baldwin [eds.], Organic phosphorus in the environment. CABI Publishing.

Raimonet, M., O. Ragueneau, F. Andrieux-Loyer, X. Philippon, R. Kerouel, M. Le Goff, and L. Mémery. 2013. Spatio-temporal variability in benthic silica cycling in two macrotidal estuaries: Causes and consequences for local to global studies. Estuarine Coastal Shelf Sci. 119: 31-43. doi:10.1016/j.ecss.2012.12.008

Rochelle-Newall, E. J., M. D. Pizay, J. J. Middelburg, H. T. S. Boschker, and J. P. Gattuso. 2004. Degradation of riverine dissolved organic matter by seawater bacteria. Aquat. Microb. Ecol. 37: 9-22. doi:10.3354/ame037009

Rose, C., and R. P. Axler. 1998. Uses of alkaline phosphatase activity in evaluating phytoplankton community phosphorus deficiency. Hydrobiologia 361: 145-156. doi: 10.1023/A:1003178502883

Ruttenberg, K. C. 2003. The global phosphorus cycle, p. 585-643. In W. H. Schlesinger [ed.], Treatise on geochemistry, V. 8. Elsevier.

Servais, P., and J. Garnier. 2006. Organic carbon and bacterial heterotrophic activity in the maximum turbidity zone of the Seine estuary (France). Aquat. Sci. 68: 78-85. doi: 10.1007/s00027-005-0809-y

Siuda, W., and R. J. Chrost. 1987. The relationship between alkaline phosphatase (APA) activity and phosphate availability for phytoplankton and bacteria in Eutrophic lakes. Acta Microb. Pol. 36: 247-257.

Smith, D. C., M. Simon, A. L. Alldredge, and F. Azam. 1992. Intense hydrolytic enzyme activity on marine aggregates and implications for rapid particle dissolution. Nature 359: 139-142. doi:10.1038/359139a0
Solórzano, L., and J. H. Sharp. 1980. Determination of total dissolved phosphorus and particulate phosphorus in natural waters. Limnol. Oceanogr. 25: 754-758. doi:10.4319/ lo.1980.25.4.0754

Steenbergh, A. K., P. L. E. Bodelier, H. L. Hoogveld, C. P. Slomp, and H. J. Laanbroek. 2011. Phosphatases relieve carbon limitation of microbial activity in Baltic Sea sediments along a redox-gradient. Limnol. Oceanogr. 56: 2018-2026. doi:10.4319/lo.2011.56.6.2018

Tietjen, T., and R. G. Wetzel. 2003. Extracellular enzymeclay mineral complexes: Enzyme adsorption, alteration of enzyme activity, and protection from photodegradation. Aquat. Ecol. 37: 331-339. doi:10.1023/B: AECO.0000007044.52801.6b

Van der Zee, C., N. Roevros, and L. Chou. 2007. Phosphorus speciation, transformation and retention in the Scheldt estuary (Belgium/The Netherlands) from the freshwater tidal limits to the North Sea. Mar. Chem. 106: 76-91. doi: 10.1016/j.marchem.2007.01.003

Velji, M. I., and L. J. Albright. 1986. Microscopic enumeration of attached marine bacteria of seawater, marine sediment, fecal matter, and kelp blade following pyrophosphate and ultrasound treatments. Can. J. Microbiol. 32: 121-126. doi:10.1139/m86-024

Zoppini, A., A. Puddu, S. Fazi, M. Rosati, and P. Sist. 2005. Extracellular enzyme activity and dynamics of bacterial community in mucilaginous aggregates of the northern Adriatic Sea. Sci. Total Environ. 353: 270-286. doi: 10.1016/j.scitotenv.2005.09.019

\section{Acknowledgment}

This research was supported by the French National Program for Coastal Environment (EC2CO). We wish to thank P. Bodenes for illustrations and the anonymous reviewers for their comments.

Submitted 29 July 2015

Revised 12 February 2016; 01 April 2016

Accepted 4 April 2016

Associate editor: Josette Garnier 